\title{
CHANGES OF EMPLOYEE MOTIVATION OF SLOVAK ENTERPRISES DUE TO GLOBAL ECONOMIC CRISIS
}

\author{
Ján Závadský, Miloš Hitka, Marek Potkány
}

\section{Introduction}

The year 2008 can be considered the beginning of the economic crisis in Slovakia when we really started to feel the pressure of the financial crisis. However, hardly anybody expected it to have such substantial impact not only on the Slovak but also on the global economy. Interaction among countries, globalisation and international relations caused a domino effect. The economic crisis can also initiate some optimisation and organisational restructuring in enterprises. At the present time a massive downsizing occurs and many companies even stop their activities. In several enterprises, after organisational restructuring and downsizing, a problem with motivation of remaining employees occurs - how to motivate them without increasing the expenses. The best way is to start using other forms of motivation and investing in development of remaining employees. The aim of the paper is to compare the changes in levels of motivation in Slovakia before the economic crisis and the current state, to define potential significant difference in level of motivation factors and subsequently to determine potential changes in levels of motivation factors that would cause the change of the enterprise motivational programme.

\section{Employee Motivation During the Economic Crisis}

The period of recession is a difficult period not only for employees but for employers, too. In a situation when the enterprise does not face the recession, the process of employee motivation is relatively simple. As the recession influences the workplace atmosphere, it is particularly difficult for each senior manager to increase employee motivation. However, if employees work with enthusiasm even during the time of recession, it can also indicate that the enterprise may recover from the recession faster and without any serious damage. Senior managers should not forget the fact that their employees are influenced also by the way they communicate with them or by the body language. All superiors who have more power, responsibility and competences should be able to motivate their team and subordinates also at the time when the first impact of the recession occurs in the enterprise [21]. When the first impact of the economic crisis occurs in the enterprise, most of traditional methods of motivation applied by the management before this time cannot be carried out. Various incentives, extra holidays, corporate entertaining and rewards which are the most commonly used tools of motivation, seem to be less important in the atmosphere of insecurity. During the recession employees lose mainly the sense of security. This situation is very stressful for employees and consequently it affects the quality and employee productivity in a negative way [5], [15]. Some methods can be used to manage the period of crisis by means of nonmonetary rewards of employees - to restructure teams, arrange educational activities in the enterprise, train employees, offer language and IT courses, management training, professional courses, seminars and trainings furthermore to benefit by several outsourcing tools of the market [17].

If the enterprise wants to keep employee productivity and their willingness to work it is appropriate to offer them motivational programme that makes them feel important for the enterprise [14].

According to the authors [4], [13], [20], [22] other ways and types of motivation applied during the economic crisis can be differentiated:

- Creating teams - building teams is a big step towards motivation that integrates all powers in the fight against barriers the 
enterprise is facing. The implementation of activities to increase skills in team building and team approach to work can be a way of motivation.

- Developing communication skills within a team - employee motivation starts with effective communication among individual team members. Lack of team support and coordination decreases motivation and creates tensions. Acquaintance and communication help overcome barriers and keep the team together in difficult times.

- Highlighting accomplishments - next most commonly used way of motivation that supports employee motivation is highlighting big and small accomplishments of the team.

- Interaction with senior management, key suppliers and customers - employee motivation should also include building strong relationship with senior management through consideration of proposals of ordinary employees and through modifying regulations as well. Motivation should create friendly approach and better proposals to solve crisis situations. Motivation is considered the key tool and the interaction extended by experience that makes solution to difficult situations easier.

- Acceptance of new ideas - employees have a feeling of togetherness, of contribution to the success of the organisation. Team leaders should take ideas of their subordinates into account.

- Harmonisation, new strategies and new trends - cooperation focusing on positive goals, progress and following the strategies of solution to crisis situations set up in advance support motivation most. It supports factors of employee motivation and team building as well.

\section{Motivational Programme as a Tool for Keeping Employee Productivity}

Since the enterprise strategy includes the goal setting and a set of tools (measures and methods) for achieving that goal, several partial strategies specifying enterprise strategies in individual activity area (e.g. marketing, investment, product development, area of finance) are expected to be created in the context of the enterprise strategy. The aim of motivational strategies is to create the work environment and to develop policy and methods that improve employee productivity.
It is very important for current employee motivation to keep right key persons working in the strategic job positions (especially those who are essential for running the enterprise). Therefore the implementation of successful motivational programmes in enterprises is considered significant. Motivational programme is, in general, a written document of the enterprise, (mostly internal) the role of which is to recruit new employees or to keep employees in required job positions and to create overall working conditions and working environment for them; to set goals and to define methods and tools of work management relating to them; to define ways of influencing negotiation at work and employee behaviour aimed at achieving the setting of goals and the schedule of gradually creating conditions to carry out the programme. Motivational programme can be considered a strategic corporate document dealing with:

- measuring motivation level in order to identify areas necessary to improve the motivation,

- creating environment where employees feel respected and rewarded by the enterprise,

- designing responsible and engaged employee behaviour in the enterprise,

- creating an empowering motivational climate in the enterprise,

- improving skills in the area of human resource management,

- designing operational tasks and new workplaces,

- managing employees` performance,

- managing the performance-based rewarding [2], [3].

When creating motivational programmes we must remember that intrinsic motivation at work is specific for each person. Therefore we define so-called motivation profile. This profile is a basic condition for creating a positive motivation. When creating motivational programme it is very useful to take into account certain rules, principles ensuring its greater responsibility, logicalness and lucidity [16]. In terms of time management the following steps need to be completed when arranging the programme.

The first step presents carrying out the analysis of motivational structure and the mood of employees in order to determine the employees' value orientation, their needs and the level of meeting their needs by means of sociological questionnaire focused on attitudes 
towards stabilisation and motivation at work. We can use quantitative, qualitative or classification analyses, generalisation, etc. After assessing the results we find out the motivational structure of different employment categories and their significance.

In the second step the goals of motivational programme are set. They will support general stability of employees in the area of stabilisation of key professions regarding current and especially future programme of production, stabilisation of skilled and hardworking employees, hiring new employees or completing the required number of employees according to the workplace planning and specification of the programme for different professional groups, management levels, etc. The results of this step of creating motivational programme are the proposals for monetary and non-monetary incentives and stimuli directly related to particular empoyees.

The third step represents the creation of the model of employment stabilisation including stimulating and motivation factors. This model includes the factors influencing stabilisation necessary for employee motivation to stay in the enterprise. Model statements, including principals and describing individual factors must be compared with reality. Factors that must be provided and those that must be solved in terms of stabilisation emerge from such comparison.

The fourth step can be described as the implementation of motivational programme. It is a specific process oriented towards employment stabilisation and the selection of ways, conditions and effective methods of stabilisation, defining methods to affect people, determining persons responsible for the implementation of motivational programme and the schedule of its fulfilling.

\section{Methodology}

Analyses of motivation in enterprises were carried out through questionnaire with structured questions. Employee attitudes concerning the issue and the basic database are presented on the basis of the responses obtained from the closed questions. Primary sample file is formed by employees of the enterprises (manufacturing and non-manufacturing) operating in the Slovak Republic. Considering the size of the sample file we could not analyse the motivation of each item of the basic sample. The random sampling was used to choose items from the basic sample. Selected sample consists of 7,724 employees. 1,118 employees participated in the research in 2008 and 6,606 employees (in different job position, mainly technical and administrative staff, and manufacturing staff) in 2013. Respondents evaluated individual motivation factors in the questionnaire (Tab. 1) by one of five levels of significance from a predefined rating scale (Tab. 2). Year 2008 was chosen as the starting point of the analyses since the level of motivation was not affected by the economic crisis. The reference period was the year 2013 when the crisis, on the basis of the macroeconomic indicators, continues.

The motivation questionnaire was created on the basis of the knowledge acquired through the long-term research [7] and through the communication with personnel clerks in the enterprises. Motivation factors that affect the employee productivity most were used in the questionnaire.

Questionnaire evaluation was carried out from the data matrix with number of employees $x$ number of motivation factors. This matrix is a data entry form for carrying out the statistical analysis of motivation factors. Questionnaires were evaluated using programme STATISTICA 7 [12]. Basic statistical characteristics were calculated for each motivation factors. They reduced information about the property of basic survey samples to a smaller number of numerical characteristics and made mutual comparison of selected samples easier. Each motivation factor was described in summary by basic characteristics [18] such as size and variability of quantitative features - mean $\bar{x}$, standard deviations $s_{x} \ldots$ Subsequently results of descriptive statistics of selected samples were compared. Besides simple comparison of descriptive characteristic values regarding the selective data collection were proceeded to the examination of equality of means and standard deviations of basic samples to prove statistical significance of differences in means and standard deviations of individual motivation factors of studied selected samples so that the fact that detected differences of descriptive characteristics at the selected level of significance $\alpha$ were not caused only by the mistake made from representative sampling was eliminated. Considering the independence of selected samples and their big sizes a twosample t-test for independent samples at the same or different variances was used. The null hypotheses about the equality of two means 


\begin{tabular}{|c|c|c|c|}
\hline SN & Motivation factor & SN & Motivation factor \\
\hline 1 & Atmosphere in the workplace & 16 & Prestige \\
\hline 2 & Good work team & 17 & Supervisor's Approach \\
\hline 3 & Further financial reward & 18 & Individual decision making \\
\hline 4 & Physical effort at work & 19 & Self - actualization \\
\hline 5 & Job security & 20 & Social benefits \\
\hline 6 & Communication in the workplace & 21 & Fair appraisal system \\
\hline 7 & Name of the company & 22 & Stress (limitation of stress in the workplace) \\
\hline 8 & Opportunity to apply own ability & 23 & Mental effort \\
\hline 9 & Workload and type of work & 24 & Mission of the company \\
\hline 10 & $\begin{array}{l}\text { Familiarisation with reached working } \\
\text { results }\end{array}$ & 25 & Region's development \\
\hline 11 & Working time & 26 & Education and personal growth \\
\hline 12 & Working environment & 27 & Company relation to the environment \\
\hline 13 & Employee productivity & 28 & Free time \\
\hline 14 & Moving up corporate ladder & 29 & Recognition \\
\hline 15 & Competences & 30 & Basic salary \\
\hline
\end{tabular}

Source: Own data processing

\section{Tab. 2: Rating scale of an order of motivation factors according to their importance}

\begin{tabular}{c|c|c|c|c}
$\mathbf{5}$ & $\mathbf{4}$ & $\mathbf{3}$ & $\mathbf{2}$ & $\mathbf{1}$ \\
\hline the most important & very important & medium important & slightly important & unimportant \\
\hline
\end{tabular}

Source: [11, p. 149]

of selected samples were tested. The null hypothesis about the equality of average values of individual motivation factors was rejected at the significance level $\alpha=0.05$.

Two-sample t-test was used to test the equality of means of motivation factors of two basic samples. When calculating t-test three cases depending upon the fact whether the variances of compared basic samples are equal or not $\left(s_{1}^{2}=s_{2}^{2}, s_{1}^{2} \neq s_{2}^{2}\right)$, or whether examined attributes $\mathrm{X}_{1}, \mathrm{X}_{2}$ are dependent or not can occur so the test of equality of variances, i.e. F-test had to be carried out at first. Following the results of F-test, the two-sample t-test for independent samples at the same or different variances was used. The null hypothesis vs. the alternative hypothesis was tested, they were as follows:

$$
H_{0}: \overline{x_{1}}=\overline{x_{2}} \quad \text { vs. } \quad H_{1}: \overline{x_{1}} \neq \overline{x_{2}}
$$

$\mathrm{H}_{0}$ : we suppose that the means of studied motivation factors in the first monitoring period are equal to means of examined motivation factors in the second monitoring period and, at the same time, we suppose that the difference between them, if there is any, is caused only by the random variation of results.

$\mathrm{H}_{1}$ : we suppose that the means of studied motivation factors in the first monitoring period are not equal to means of examined 
motivation factors in the second monitoring period and, at the same time, we suppose that the difference between them, if there is any, is not caused only by the random variation of results.

The random variable $t$ was used as a test criterion. The Student's $t$ distribution was as follows:

- if $s_{1}^{2}=s_{2}^{2} ; X_{1}$ and $X_{2}$ are independent

$$
t=\frac{\bar{x}_{1}-\bar{x}_{2}}{\sqrt{\frac{n_{1} \cdot s_{1}^{2}+n_{2} \cdot s_{2}^{2}}{n_{1}+n_{2}-2} \cdot \frac{n_{1}+n_{2}}{n_{1} \cdot n_{2}}}}
$$

- if $s_{1}^{2} \neq s_{2}^{2} ; X_{1}$ and $X_{2}$ are independent

$$
t=\frac{\bar{x}_{1}-\bar{x}_{2}}{\sqrt{\frac{s_{1}^{2}}{n_{1}-1}+\frac{s_{2}^{2}}{n_{2}-1}}}
$$

The variable $F$ was used as a test criterion for the equality of variances and the Fisher $F$ division was as follows: $\mathrm{F}=\frac{s_{1}^{2}}{s_{2}^{2}}$. In the end of the test we evaluated the level of significance p. In a case that $p<\alpha=0.05$, we reject the null hypothesis about the equality of means and variances.

\section{Results}

The Tab. 3 shows the order of the most important motivation factors and their means in 2008 and 2013. In the year 2008 factors relating to the relationship (atmosphere in the workplace, supervisor's approach, good work team, communication in the workplace) and job security took the leading positions and in the year 2013 factors like job security and financial incentives (basic salary and fair appraisal system) became more important. The importance of factors relating to the relationship (good work team, atmosphere in the workplace, supervisor's approach and communication in the workplace) decreased. Only 3 motivation factors (in 2008 employee productivity, name of the company, education and personal growth and in 2013 further financial reward, social benefits, working time), from 10 which are considered by employees to be the most important, changed the position during the examined period. We can point out that the motivation, in the area of changed motivation factors in 2008 and 2013, was influenced by changes in economic situation and employees were focused mainly on financial reward and social benefits.

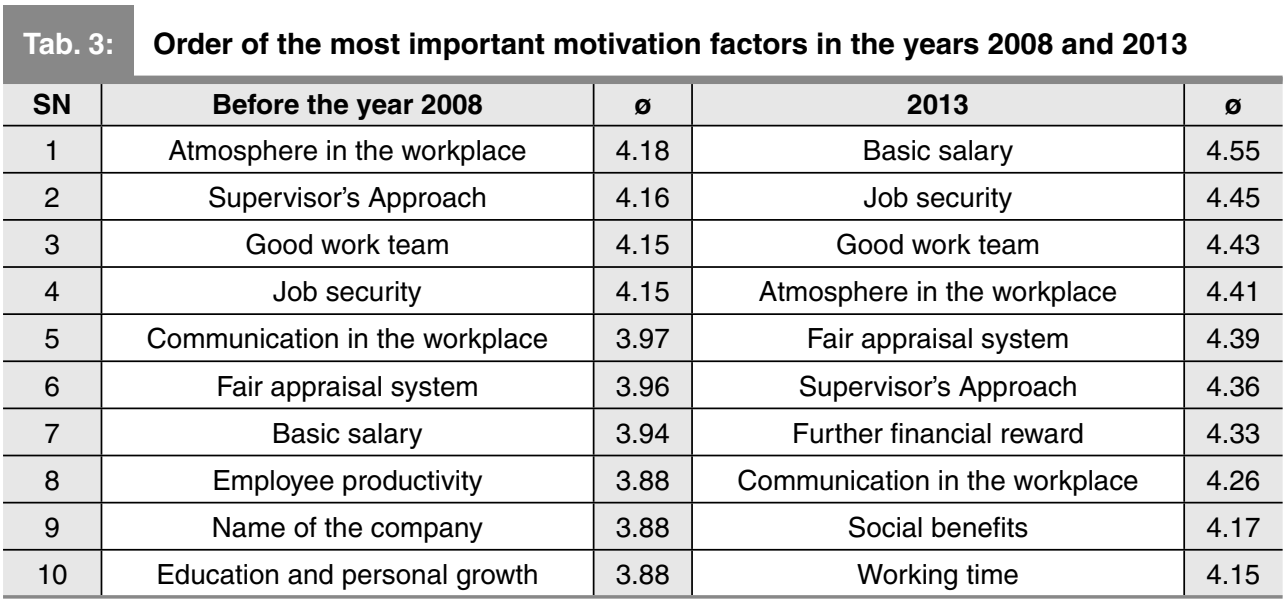


In terms of significance of individual motivation factors we can state that all motivation factors (besides name of the company) changed significantly at the level $\alpha<0.001$, whereby we confirm the hypothesis $\mathrm{H}_{1}$ (Tab. 4). In Tab. 4 we can see means of motivation factors in the year 2008 and 2013. The difference of means in the monitoring period is shown in the second column.
The significant change in the monitoring period can be seen in the column $p$. All motivation factors, besides the factor the name of the company, are considered significant. From stated findings it is possible, but difficult, to predict the development of motivation, providing that we are familiar with external and internal economic conditions. It is evident also in our analyses.

\section{Tab. 4: Means and the level of significance $p$ for individual motivation factors (part 1)}

\begin{tabular}{|c|c|c|c|c|c|c|c|c|c|}
\hline & ø 2008 & ø 2013 & $\begin{array}{l}ø 2013- \\
\varnothing 2008\end{array}$ & t-value & $p$ & $\begin{array}{l}\text { Std. } \\
\text { Dev. } \\
2008\end{array}$ & $\begin{array}{l}\text { Std. } \\
\text { Dev. } \\
2013 \\
\end{array}$ & $\begin{array}{c}\text { F-ratio } \\
\text { Varian- } \\
\text { ces }\end{array}$ & $\begin{array}{c}\mathbf{p} \\
\text { Variances }\end{array}$ \\
\hline $\begin{array}{l}\text { Atmosphere in the } \\
\text { workplace }\end{array}$ & 4.18 & 4.41 & 0.23 & -8.87 & 0.00000 & 0.906 & 0.788 & 1.32 & 0.00000 \\
\hline Good work team & 4.15 & 4.43 & 0.27 & -10.90 & 0.00000 & 0.928 & 0.744 & 1.56 & 0.00000 \\
\hline Further financial reward & 3.75 & 4.33 & 0.58 & -20.41 & 0.00000 & 1.211 & 0.805 & 2.26 & 0.00000 \\
\hline Physical effort at work & 3.41 & 3.81 & 0.40 & -12.78 & 0.00000 & 1.022 & 0.949 & 1.16 & 0.00087 \\
\hline Job security & 4.15 & 4.45 & 0.30 & -11.50 & 0.00000 & 0.962 & 0.788 & 1.49 & 0.00000 \\
\hline $\begin{array}{l}\text { Communication in the } \\
\text { workplace }\end{array}$ & 3.97 & 4.26 & 0.29 & -10.78 & 0.00000 & 0.975 & 0.818 & 1.42 & 0.00000 \\
\hline $\begin{array}{l}\text { Name } \\
\text { of the company }\end{array}$ & 3.88 & 3.80 & -0.08 & 2.42 & 0.01545 & 0.977 & 1.071 & 1.20 & 0.00008 \\
\hline $\begin{array}{l}\text { Opportunity to allow } \\
\text { own ability }\end{array}$ & 3.73 & 4.00 & 0.27 & -9.30 & 0.00000 & 1.023 & 0.884 & 1.34 & 0.00000 \\
\hline $\begin{array}{l}\text { Workload and type } \\
\text { of work }\end{array}$ & 3.70 & 4.04 & 0.34 & -12.02 & 0.00000 & 1.029 & 0.844 & 1.49 & 0.00000 \\
\hline $\begin{array}{l}\text { Familiarisation with } \\
\text { reached working results }\end{array}$ & 3.54 & 3.95 & 0.41 & -13.49 & 0.00000 & 1.157 & 0.900 & 1.65 & 0.00000 \\
\hline Working time & 3.85 & 4.15 & 0.30 & -10.52 & 0.00000 & 1.020 & 0.862 & 1.40 & 0.00000 \\
\hline $\begin{array}{l}\text { Working } \\
\text { environment }\end{array}$ & 3.81 & 4.13 & 0.31 & -11.12 & 0.00000 & 1.003 & 0.851 & 1.39 & 0.00000 \\
\hline $\begin{array}{l}\text { Employee } \\
\text { productivity }\end{array}$ & 3.88 & 4.09 & 0.21 & -7.50 & 0.00000 & 0.947 & 0.859 & 1.21 & 0.00001 \\
\hline $\begin{array}{l}\text { Moving up corporate } \\
\text { ladder }\end{array}$ & 3.80 & 4.00 & 0.20 & -6.81 & 0.00000 & 1.039 & 0.891 & 1.36 & 0.00000 \\
\hline Competences & 3.51 & 3.86 & 0.35 & -11.24 & 0.00000 & 1.139 & 0.945 & 1.45 & 0.00000 \\
\hline Prestige & 3.36 & 3.68 & 0.32 & -9.64 & 0.00000 & 1.071 & 1.008 & 1.13 & 0.00719 \\
\hline $\begin{array}{l}\text { Supervisor's } \\
\text { Approach }\end{array}$ & 4.16 & 4.36 & 0.21 & -7.71 & 0.00000 & 0.905 & 0.810 & 1.25 & 0.00000 \\
\hline $\begin{array}{l}\text { Individual decision } \\
\text { making }\end{array}$ & 3.65 & 3.98 & 0.33 & -11.30 & 0.00000 & 1.018 & 0.885 & 1.32 & 0.00000 \\
\hline Self - actualization & 3.68 & 3.97 & 0.29 & -9.68 & 0.00000 & 1.046 & 0.887 & 1.39 & 0.00000 \\
\hline Social benefits & 3.64 & 4.17 & 0.53 & -17.43 & 0.00000 & 1.228 & 0.873 & 1.98 & 0.00000 \\
\hline Fair appraisal system & 3.96 & 4.39 & 0.43 & -14.92 & 0.00000 & 1.187 & 0.824 & 2.08 & 0.00000 \\
\hline $\begin{array}{l}\text { Stress /limitation of } \\
\text { stress in the workplace/ }\end{array}$ & 3.75 & 4.03 & 0.27 & -8.88 & 0.00000 & 1.063 & 0.937 & 1.29 & 0.00000 \\
\hline
\end{tabular}


Tab. 4: Means and the level of significance $p$ for individual motivation factors (part 2)

\begin{tabular}{l|c|c|c|c|c|c|c|c|c} 
& $\boldsymbol{\sigma} \mathbf{2 0 0 8}$ & $\boldsymbol{\sigma 2 0 1 3}$ & $\begin{array}{c}\boldsymbol{\sigma} \mathbf{2 0 1 3}- \\
\boldsymbol{\sigma 2 0 0 8}\end{array}$ & $\mathrm{t}-\mathrm{value}$ & $\mathbf{p}$ & $\begin{array}{c}\text { Std. } \\
\text { Dev. } \\
\mathbf{2 0 0 8}\end{array}$ & $\begin{array}{c}\text { Std. } \\
\text { Dev. } \\
\mathbf{2 0 1 3}\end{array}$ & $\begin{array}{c}\text { F-ratio } \\
\text { Varian- } \\
\text { ces }\end{array}$ & $\begin{array}{c}\mathbf{p} \\
\text { Variances }\end{array}$ \\
\hline Mental effort & 3.61 & 3.95 & 0.34 & -10.86 & 0.00000 & 1.050 & 0.940 & 1.25 & 0.00000 \\
\hline Mission of the company & 3.69 & 3.81 & 0.13 & -3.86 & 0.00012 & 1.083 & 1.002 & 1.17 & 0.00055 \\
\hline Region's development & 3.42 & 3.76 & 0.34 & -9.66 & 0.00000 & 1.143 & 1.062 & 1.16 & 0.00109 \\
\hline $\begin{array}{l}\text { Education and personal } \\
\text { growth }\end{array}$ & 3.88 & 3.99 & 0.11 & -3.66 & 0.00025 & 1.112 & 0.937 & 1.41 & 0.00000 \\
\hline $\begin{array}{l}\text { Company relation to the } \\
\text { environment }\end{array}$ & 3.74 & 3.87 & 0.13 & -3.86 & 0.00011 & 1.044 & 1.028 & 1.03 & 0.48275 \\
\hline Free time & 3.65 & 4.06 & 0.42 & -13.18 & 0.00000 & 1.108 & 0.951 & 1.36 & 0.00000 \\
\hline Recognition & 3.68 & 4.13 & 0.44 & -14.94 & 0.00000 & 1.115 & 0.881 & 1.60 & 0.00000 \\
\hline Basic salary & 3.94 & 4.55 & 0.61 & -22.08 & 0.00000 & 1.210 & 0.779 & 2.41 & 0.00000 \\
\hline
\end{tabular}

Note: $n_{1}=1118, n_{2}=6606$

\section{Conclusion}

Within our actual analyses we can point out that employees need to stay motivated also from a long-term point of view (the research carried out in 2001-2011 by authors [9], [19], [6], [7], [8], [11], [10]). It is evident in the analyses in enterprises where the significant change of motivation occurred in a period of five years.

Following the performed analyses (statistical single factor analysis of variance and Duncan's test) we can define the difference in the level of motivation factors before the financial crisis and at the present time. Subsequently we can state that changes that happened were not caused by random effect or by action of some other significant effects. The economic crisis can be considered a significant factor causing changes in the employee motivation.

When analysing the employee motivation in the enterprises in Slovakia during the researched period we found out that among ten most important motivation factors there are following essential motivation factors: monetary incentives (basic salary, fair appraisal system, further financial reward), motivation factors based on the job security or human relationships (atmosphere in the workplace, good work team, supervisor's approach, communication in the workplace) and motivation factors based on working conditions (employee productivity, working time, working environment). At the present time we can observe significant changes of employee motivation in the Slovak enterprises before and during the financial crisis. That allows us to draw a conclusion that the level of motivation depends on microeconomic and macroeconomic aspects not only in an enterprise but also in a whole society.

We can also state that employees are fully aware of the importance of the job security in the period of recession and the fact that the society cannot offer them required financial reward. Therefore the enterprises should focus on the process of motivation especially by means of motivation factors based on human relationships and job security. Similar results were found out also by the author Irena Bakanauskiene in cooperation with Mindaugas Ubartas [1]. She concluded that, in the period of recession, employers tend to improve the process of employee motivation in enterprises and job dissatisfaction is decreasing on average, what is in accordance with individual factors differentiated in Maslow's hierarchy of needs. They also found out that the number of unaffected factors decreased and employees tend to improve working conditions through motivation. Detailed analysis of individual factors according to described groups allows us to suppose that during the time of economic crisis:

- the effect of motivation factors increased and employees consider them more motivating, 
- the most important motivation factor became the success as well as recognition, personal growth and the job itself,

- employee dissatisfaction with the work control system and consequential variability of financial reward increased,

- the number of factors employees consider neutral in their job decreases and they accept that superiors should not pay attention to personal life of employees and relationship with subordinates,

- the significance of the employers' interest in needs of their employees relating to individual motivation factors as well as the appraisal system of employees, their security or working conditions increase.

Compared to the time before the beginning of the economic crisis following changes in individual groups of motivation factors were observed:

- the impact of recognition, responsibility and success increased,

- the dissatisfaction of employees increased in the areas of job control and financial reward.

There is another significant research finding. It is the fact that fair performance appraisal system in the enterprise is essential also in the time of the financial crisis because employee work results are closely related to it [1].

The result of the analysis carried out by the authors [13] is the finding that more and more enterprises focus on meeting the need of job security outlook which is one of the most important motivation factors at present.

In the period of recession it is very important to ensure job security and to build positive relationship among employees and this can be achieved through effective communication. However, employers do not pay enough attention to this need. The research shows that employers rarely allow employees to meet this need and it can demotivate them. The motivation factors - reward, recognition and employee engagement in problem solving process are also effective motivation factors themselves. The results of mentioned research confirm our findings.

During the time of the financial crisis it is necessary to think about motivation factors fwith focus on on building human relationships, job security, or factors concerning working conditions followed by financial motivation factors. Latter mentioned factor takes the leading position during the time of the enterprise recovery.

This paper was supported by the project VEGA No. 1/0067/11 Dynamics and content of decision-taking processes in motivating of human potential and VEGA No. 1/0268/13 "Perspectives of facility management application for the increasing of competitiveness within the woodprocessing and forestry companies in the context of outsourcing principles" and KEGA project No. 037STU-4/2012 "Implementation of the subject "Corporate Social Responsibility Entrepreneurship" into the study programme Industrial management".

\section{References}

[1] BAKANAUSKIENE, I., UBARTAS, M. The changes of employee's motivation in the crisis conditions. Impresa Progetto. 2012, Iss. 1, pp. 8-9. ISSN 1824-3576.

[2] BLAŠKOVÁ, M., GRAZULIS, V. Motivation of human potential: Theory and practice. Mikolas Romeris University, Zilina University, 2009. 502 p. ISBN 978-9955-19-155-1.

[3] BLAŠKOVÁ, M. Correlations between the Increase in Motivation and Increase in Quality. E+M Ekonomie a Management. 2009, Vol. 12, Iss. 4, pp. 54-68. ISSN 1212-3609.

[4] CANSTAR. Global Financial Crisis - What caused it and how the world responded [online]. 2009 [cit. 2013-02-08]. Available from: http:// www.canstar.com.au/home-loans/globalfinancial-crisis/.

[5] HARANKHEDKAR, H. How to Motivate Employees During a Recession [online]. 2011 [cit. 2013- 02-08]. Available from: http:// www.buzzle.com/articles/how-to-motivateemployees-during-a-recession.html/.

[6] HITKA, M. Analýza vývoja motivačných faktorov robotníkov v Slovenských elektrárňach Mochovce v rokoch 2003-2005. Ekonomické rozhlady. 2007, Iss. 2, pp. 256-263. ISSN 0323262X.

[7] HITKA, M. Zhodnotenie výskumu motivácie zamestnancov vo výrobných podnikoch Slovenska za roky 2000-2008. In: Konferencia MLPVP. Žilina, 2009. ISBN 978-80554-0013-6.

[8] HITKA, M. Model analýzy motivácie zamestnancov výrobných podnikov. Zvolen: ES TU Zvolen, 2009. 150 p. ISBN 978-8022819985. 
[9] HITKA, M., BLAŠKOVÁ, M. Vývoj motivácie zamestnancov Bučina, a. s. Zvolen. Ekonomika a manažment podniku. 2006, Iss. 1, pp. 69-82. ISSN 1336-4103.

[10] HITKA, M., SIROTIAKOVÁ, M. Impact of economic crisis on change of motivation of Ekoltech s. r. o. Filakovo employees. Drewno wood. 2011, Vol. 54, Iss. 185, pp. 119-126. ISSN 1644-3985.

[11] HITKA, M., VACEK, V. Changes in motivation of workers in production in a production company as a result of the economic crisis. In: MVK Human Potential Development: Search for Opportunities in the New EU States. Vilnius: Mykolas Romeris University, 2010. ISBN 978-9955-19-181-0.

[12] StatSoft, Inc. STATISTICA (data analysis software system). Version 7. www.statsoft.com. 2004.

[13] KROPIVŠEK, J., JELAČIĆ, D., GROŠELJ, P. Motivating employees of slovenian and croatian wood industry companies in times of economic downturn. Drvna industrija. 2011, Vol. 62, No. 2, pp. 97-103. ISSN 0012-6772. doi:10.5552/drind.2011.1040.

[14] MEERASAIGAL. How to Motivate Employees During a Recession [online]. 2012 [cit. 2013-02-08]. Available from: http:// www.jobjasoos.com/blog/how-to-motivateemployees-during-a-recession/.

[15] MEYERSON, H. Keeping Employees Motivated During a Crisis [online]. 2012 [cit. 2013-02-11]. Available from: http://www. confidencecenter.com/art24.htm/.

[16] MYŠKOVÁ, R. Metodika hodnocení spokojenosti pracovníků. E+M Ekonomie a Management. 2005, Vol. 8, Iss. 1, pp. 84-97. ISSN 1212-3609.

[17] POTKÁNY, M. Personnel outsourcing processes. E+M Ekonomie a Management. 2008, Vol. 11, Iss. 4, pp. 53-62. ISSN 1212-3609. [18] RIMARČíK, M. Dvojrozmerná induktívna štatistika - intervalová premenná a nominálna premenná - nezávislé vzorky. Jednofaktorová analýza rozptylu [online]. 2013 [cit. 2013-03-05]. Available from: http://rimarcik.com/navigator/1anova.html.

[19] VETRÁKOVÁ, M., HITKA, M., SEDMÁK, R. Analýza vývoja motivácie robotníkov v Slovenských elektrárňach a. s. Mochovce $\mathrm{z}$ časového a vecného hladiska. E+M Ekonomie a Management. 2007, Vol. 10, Iss. 1, pp. 84-97. ISSN 1212-3609.

[20] VETRÁKOVÁ, M., ĎURIAN, J., ELEXOVÁ, G., SEKOVÁ, M. L'udské zdroje a ich riadenie. Zvolen: Bratia Sabovci, 2011. 206 p. ISBN 97880-557-0149-3.

[21] TEPLICKÁ, K. Progresívne trendy riadenia výrobných podnikov. E+M Ekonomie a Management. 2004, Vol. 7, Iss. 4, pp. 26-31. ISSN 1212-3609.

[22] ZÁVADSKÁ, Z. Využívanie procesného modelu podniku $v$ práci manažérov. In: Human Potential in a Company. Univerzita Mateja Bela Banská Bystrica, 2012. pp. 484-491. ISBN 97880-8075-535-5.

\section{prof. Ing. Ján Závadský, PhD. Matej Bel University Faculty of Economics Institute of Managerial Systems jan.zavadsky@umb.sk \\ doc. Ing. Miloš Hitka, PhD. Technical University in Zvolen milos.hitka@tuzvo.sk} Faculty of Wood Sciences and Technology

doc. Ing. Marek Potkány, PhD.

Technical University in Zvolen Faculty of Wood Sciences and Technology marek.potkany@tuzvo.sk 


\title{
Abstract
}

\section{CHANGES OF EMPLOYEE MOTIVATION OF SLOVAK ENTERPRISES DUE TO GLOBAL ECONOMIC CRISIS}

\author{
Ján Závadský, Miloš Hitka, Marek Potkány
}

Nowadays, at the time of economic globalisation and the European labour market formation, it is possible to carry out different analyses which enable comparsions among enterprises from the geopolitical, economical and commercial point of view. In the paper we compare the level of employee motivation in the Slovak enterprises before the beginning of the economic crisis in 2008 and in 2013 when the impact of the crisis has already been felt intensely. The year 2008 was chosen as the starting point of the analyses since the level the level of motivation was not affected by the economic crisis. The reference period was the year 2013 when the crisis, on the basis of the macroeconomic indicators, continues. Basic research sample is formed by employees of the enterprises (manufacturing and non-manufacturing) operating in the Slovak Republic. Considering the size of the basic sample we could not analyse the motivation of each item of the basic sample. The random sampling was used to choose items from the basic sample. The motivation questionnaire was created on the basis of the knowledge acquired through the longterm research and through the communication with personnel clerks in the enterprises. Motivation factors that affect the employee productivity the most were used in the questionnaire. Following the sizes of selected samples and their independence we used a two-sample t-test to determine the significance. The null hypothesis testing about equality of means of individual motivation factors in the particular period of time was carried out at the significance level $\alpha=0.05$. Following the results of analyses we state that employees need to stay motivated also from a long-term point of view. However, essential changes occur in order of importance. We can state that in the circumstances of changed motivation factors in the year 2008 and 2013 the motivation was affected by changes in economic situation and employees are focused on monetary incentives and relationship factors more.

Key Words: Motivation, motivational programme, change of motivation, economic crisis, two-sample t-test, Duncan's test.

JEL Classification: M12.

DOI: 10.15240/tul/001/2015-1-005 